\title{
B4
}

doi: $10.14232 /$ fgykf.2018.b4

\section{A junkuenin B félszintetikus származékainak előállítása és a vegyületek antiproliferatív hatásának vizsgálata}

Bús Csaba ${ }^{1}$ Kúsz Norbert, ${ }^{1}$ Kulmány Ágnes, ${ }^{2}$ Zupkó István, ${ }^{2}$ Tóth Barbara, ${ }^{1}$ Hohmann Judit, ${ }^{1}$ Hunyadi Attila, ${ }^{1}$ Vasas Andrea ${ }^{1}$

${ }^{1}$ Szegedi Tudományegyetem, Interdiszciplináris Kiválósági Központ, Farmakognóziai Intézet, 6720 Szeged, Eötvös u. 6.

${ }^{2}$ Szegedi Tudományegyetem, Interdiszciplináris Kiválósági Központ, Gyógyszerhatástani és Biofarmáciai Intézet, 6720 Szeged, Eötvös u. 6.

A junkuenin B a fenantrének közé tartozó, növényi eredetű, aromás metabolit. A fenantrének szerkezeti és biológiai sokszínűségüknek köszönhetően jelentős tudományos érdeklődést váltottak ki az elmúlt években. Számos kutatócsoport számolt be többek között a vegyületek in vitro citotoxikus, antiproliferatív, gyulladáscsökkentő és antimikrobiális hatásáról.

A protoflavonok a flavonoidok egy különleges csoportját alkotják, szerkezeti jellemzőik a nem aromás B gyürü, és egy hirdoxilcsoport kapcsolódása a C-1' szénatomhoz (1. ábra). Számos természetes és félszintetikus vegyület vizsgálata során mértek ígéretes antiproliferatív aktivitást; farmakofórként a para-kinol szerkezetű B gyürüt azonosították.
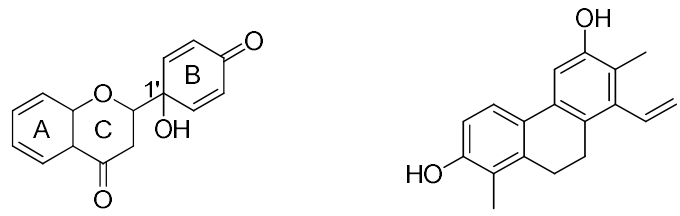

1. ábra A protoflavonok és a junkuenin B szerkezete

Nagyszámú fenantrén, köztük a junkuenin B is fenolos hidroxilcsoportokat tartalmaz, amelyek révén oxidációs reakciókban protoflavonszerú para-kinol gyürüt tartalmazó vegyületek keletkezhetnek. Kísérleteink célja ilyen fenantrénszármazékok előállítása és farmakológiai vizsgálata volt.

A reakciókhoz speciális oxidálószereket [bisz-trifluoroacetoxi-jodobenzol (PIFA) és diacetoxi-jodobenzol (PIDA)] alkalmaztunk különböző reakciókörülmények között. A 
reakciókeverékek tisztítását szilárd fázisú extrakcióval, közepes nyomású-, és nagyhatékonyságú folyadékkromatográfiás módszerrel (MPLC, HPLC) végeztük. A vegyületek szerkezetének meghatározása $1 D$ és 2D NMR spektroszkópiai módszerekkel történt.

Munkánk eredményeként 11 vegyületet állítottunk elő, többségük para-kinol gyűrűvel rendelkezik. Számos anyag mutatott ígéretes in vitro antiproliferatív hatást.

Köszönetnyilvánítás: A kutatást az Emberi Erőforrások Minisztériuma UNKP-18-3 kódszámú Új Nemzeti Kiválóság Programja és a 20391-3/2018/FEKUSTRAT, valamint az NKFIH (K128963) támogatta.

Témavezető: Dr. Vasas Andrea 